\title{
Soil and vegetation responses to sewage sludge on a degraded semiarid broom snakeweed/blue grama plant community
}

\author{
P.R. FRESQUEZ, RICHARD E. FRANCIS, AND G.L. DENNIS
}

\begin{abstract}
Three rates of dried sewage sludge (22.5, 45.0, and $90.0 \mathrm{Mg}$ (megagrams) $\mathrm{ha}^{-1}$ ), were applied to a degraded semiarid grassland site on the Upper Rio Puerco Watershed in west-central New Mexico. Various soil and plant parameters were determined over 4 growing seasons. Most soil macronutrients, such as nitrogen (N), phosphorus ( $P$ ), and potassium (K), and micronutrients, such as copper $(\mathrm{Cu})$, iron $(\mathrm{Fe})$, manganese $(\mathrm{Mn})$, and zinc $(\mathrm{Zn})$, increased linearly with increasing sludge amendment rates. Heavy metals (cadium ( $\mathrm{Cd}$ ) and lead $(\mathrm{Pb})$ ) did not change as a result of sludge amendment in the first 3 growing seasons. However, concentrations of soil $\mathrm{Cu}, \mathrm{Mn}$, and $\mathrm{Cd}$ were just above maximum acceptable standards in the heaviest sludge treatment after 4 growing seasons. Plant density, species richness, and diversity all decreased with increasing sludge rates. However, total plant foliar cover and herbaceous yields increased significantly with the application of sludge. Blue grama (Bouteloua gracilis (H.B.K.) Lag.) cover and yields, in particular, increased 2 to 3 fold over the control as a result of sludge amendment, whereas broom snakeweed (Gutierrezia sarothrae (Pursh) Britt. + Rusby) density decreased over 4 growing seasons. The most favorable soil and vegetation results were from the 22.5 and the $45 \mathrm{Mg} \mathrm{ha}^{-1}$ sludge application rates.
\end{abstract}

Key Words: nutrient cycling, heavy metals, herbage yields, foliar cover, organic amendment, grassland rehabilitation, New Mexico

\footnotetext{
Authors are soil scientist, range scientist, and graduate research assistant, USDA Forest Service, Rocky Mountain Forest and Range Experiment Station, Albuquerque, New Mexico 7106. The present address of P.R. Fresquez is Los Alamos National Laboratory, K490, Los Alamos, NM 87545.

This research was conducted in cooperation with the USDI Bureau of Land Management.

Manuscript accepted 19 October 1989.
}

The Upper Rio Puerco Watershed in west-central New Mexico has a long history of heavy livestock grazing and erosion (Dortignac 1960). The herbaceous plant foliar cover may be as low as 5 to $20 \%$ (Francis 1986). The low plant cover combined with infrequent but intense thunderstorms have made the Rio Puerco Watershed one of the most severely eroded areas in the United States (Scholl and Aldon 1988). In fact, the Rio Puerco Watershed accounts for over $56 \%$ of the sediment load to the Rio Grande (Waite 1972).

Numerous treatments designed to reduce erosion have been tested on the Rio Puerco Watershed (Hickey and Dortignac 1964, Aldon and Garcia 1972). Most of this research has concentrated on physical treatments designed to decrease siltation by impeding overland flow and increasing water infiltration. Little work, however, has been done to test the effects of fertilizer or organic amendments on such degraded sites to increase plant cover and production.

Nitrogen $(\mathrm{N})$ and phosphorus $(\mathrm{P})$ fertilizers have been shown to increase herbage yield and improve forage quality in semiarid grasslands (Black and Wight 1979). However, $N$ and P fertilizers are costly and dependent on effective precipitation. In contrast to synthetic fertilizers, organic amendments are relatively inexpensive, environmentally acceptable, and less dependent on seasonal precipitation by providing a mulch layer in addition to nutrients. Stabilized sewage sludge appeared well suited for such a use (Fresquez et al. 1988a).

Stabilized sewage sludge has potential for amending degraded calcareous grassland soils by replenishing organic matter (OM) and acting as a low-grade slow-release fertilizer (McCaslin and O'Connor 1982). As an organic amendment, dried sewage sludge 
Table 1. Chemical and physical properties of a pretreatment Rio Puerco silty clay loam soil (means from 16 plots) and dried Albuquerque sewage sludge.

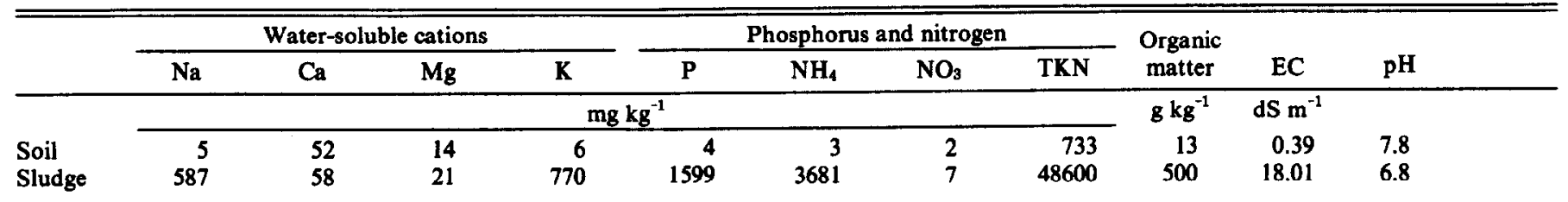

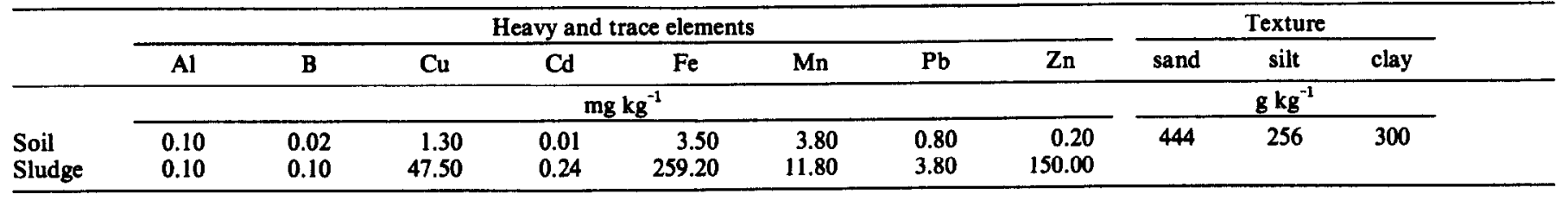

can be expected to increase soil cation exchange capacity and plant water-use efficiency, while improving soil aggregation and tilth (Erickson 1973). As a slow-release fertilizer, sewage sludge can be expected to add essential plant nutrients through soil biological processes of decomposition, oxidation, and reduction (Sommers 1977).

Studies of nutrient cycling on the Rio Puerco, have shown that many of these soils are extremely low in organic matter and plant available N (Fresquez et al. 1988b, Aldon et al. 1988, Whitford et al. 1989). The objective of this study was to determine the effect of 3 application rates of dried sewage sludge on soil and vegetation properties of a degraded grassland site. The responses of the soil microbial community (Dennis and Fresquez 1989), and changes in plant quality (Fresquez et al. 1990) from these same sludgeamended soils have been described previously.

\section{Materials and Methods}

In June 1985, dried, anaerobically digested sewage sludge from Albuquerque, New Mexico, was surface-applied to a degraded semiarid grassland site on the Rio Puerco Watershed $70 \mathrm{~km}$ northwest of Albuquerque. Sewage sludge was applied at rates of
$0,22.5,45.0$, and $90.0 \mathrm{Mg}$ (megagrams) $\mathrm{ha}^{-1}$ to each of four 3- $\times$ $20-\mathrm{m}$ plots, in a randomized complete block design of 16 plots. The area was fenced to prevent disturbance. The study site was classified as a snakeweed/blue grama-galleta (Gutierrezia sarothrae (Pursh) Britt + Rusby/Bouteloua gracilis (H.B.K.)Lag.-Hilaria jamesii (Torr.) Benth.) plant community on a Litle silty clay loam, a member of the fine, mixed, mesic mollic Camborthids (USDA, 1986) - a prevalent and representative degraded grassland site in the Rio Puerco study area (Francis 1986).

Soil samples were taken from nonrhizosphere soil from each of the 16 plots in June 1985 (pretreatment), and each August from 1985 through 1988 . Five randomly located subsamples from each plot were taken from a depth of $15 \mathrm{~cm}$ with a $5 \mathrm{~cm}$ diameter bucket auger. Subsamples were composited in sealable, sterile plastic containers, placed in an ice-chest, and transported back to the laboratory where the soils were passed through a 2-mm sieve. All 16 composite soil samples from each of the 5 sampling dates and sludge samples were analyzed for numerous chemical and physical properties (Table 1). All methods of soil chemical and physical analysis have been described previously (Dennis and Fresquez 1989). Heavy metal and micronutrient concentrations, except hot

Table 2. Chemical properties from an unamended and sewage sludge amended grassland soils.

\begin{tabular}{|c|c|c|c|c|c|c|c|c|c|c|c|}
\hline \multirow{2}{*}{$\begin{array}{l}\text { Treatment } \\
\left(\mathrm{Mg} \mathrm{ha}^{-1}\right)\end{array}$} & \multicolumn{4}{|c|}{ Water-soluble cations } & \multicolumn{4}{|c|}{ Phosphorus and nitrogen } & \multirow{2}{*}{$\begin{array}{l}\text { Organic } \\
\text { matter }\end{array}$} & \multirow[b]{2}{*}{ EC } & \multirow[b]{2}{*}{ pH } \\
\hline & $\mathbf{N a}$ & $\mathrm{Ca}$ & $\mathbf{M g}$ & $\mathbf{K}$ & $\mathbf{P}$ & $\mathrm{NH}_{4}$ & $\mathrm{NO}_{3}-\mathrm{N}$ & TKN & & & \\
\hline & \multicolumn{8}{|c|}{$\mathrm{mg} \mathrm{K}_{\mathrm{g}}{ }^{-1}$} & $\mathrm{~g} \mathrm{~kg}^{-1}$ & $\mathrm{dS} \mathrm{m} \mathrm{m}^{-1}$ & \\
\hline $\begin{array}{c}0 \\
22.5 \\
45 \\
90\end{array}$ & $\begin{array}{l}11 c^{1} \\
22 c \\
39 b \\
59 a\end{array}$ & $\begin{array}{l}43 c \\
134 b c \\
201 a b \\
256 a\end{array}$ & $\begin{array}{l}11 \mathrm{c} \\
29 \mathrm{bc} \\
46 \mathrm{ab} \\
56 a\end{array}$ & $\begin{array}{r}6 b \\
10 b \\
17 a \\
19 a\end{array}$ & $\begin{array}{c}5 c \\
15 b c \\
20 b \\
31 a\end{array}$ & $\begin{array}{c}1985 \\
3 \mathrm{~b} \\
9 \mathrm{~b} \\
20 \mathrm{ab} \\
51 \mathrm{a}\end{array}$ & $\begin{array}{l}2 \mathrm{~b} \\
22 \mathrm{ab} \\
42 \mathrm{ab} \\
61 \mathrm{a}\end{array}$ & $\begin{array}{l}729 b \\
817 a b \\
845 a b \\
924 a\end{array}$ & $\begin{array}{l}12 a \\
13 a \\
14 a \\
12 a\end{array}$ & $\begin{array}{l}0.36 \mathrm{c} \\
1.06 \mathrm{bc} \\
1.66 \mathrm{ab} \\
2.23 \mathrm{a}\end{array}$ & $\begin{array}{l}7.8 \mathrm{a} \\
7.7 \mathrm{ab} \\
7.6 \mathrm{~b} \\
7.5 \mathrm{~b}\end{array}$ \\
\hline $\begin{array}{c}0 \\
22.5 \\
45 \\
90\end{array}$ & $\begin{array}{l}11 \mathrm{~b} \\
27 \mathrm{ab} \\
27 \mathrm{ab} \\
55 \mathrm{a}\end{array}$ & $\begin{array}{l}47 b \\
133 a b \\
168 a b \\
264 a\end{array}$ & $\begin{array}{l}13 \mathrm{~b} \\
33 \mathrm{ab} \\
44 \mathrm{ab} \\
71 \mathrm{a}\end{array}$ & $\begin{array}{c}4 b \\
9 a b \\
12 a b \\
20 a\end{array}$ & $\begin{array}{c}4 c \\
20 b c \\
44 b \\
72 a\end{array}$ & $\begin{array}{c}1986 \\
3 c \\
10 b c \\
22 b \\
39 a\end{array}$ & $\begin{array}{l}1 c \\
10 b c \\
28 b \\
54 a\end{array}$ & $\begin{array}{l}665 b \\
828 a b \\
843 a b \\
987 a\end{array}$ & $\begin{array}{l}14 a b \\
15 a \\
15 a b \\
12 b\end{array}$ & $\begin{array}{l}0.37 \mathrm{~b} \\
0.96 \mathrm{ab} \\
1.26 \mathrm{ab} \\
1.97 \mathrm{a}\end{array}$ & $\begin{array}{l}7.8 \mathrm{a} \\
7.6 \mathrm{ab} \\
7.4 \mathrm{~b} \\
7.4 \mathrm{~b}\end{array}$ \\
\hline $\begin{array}{c}0 \\
22.5 \\
45 \\
90\end{array}$ & $\begin{array}{c}3 \mathrm{~b} \\
3 \mathrm{~b} \\
6 \mathrm{ab} \\
13 \mathrm{a}\end{array}$ & $\begin{array}{c}47 \mathrm{~b} \\
93 \mathrm{ab} \\
100 \mathrm{ab} \\
155 \mathrm{a}\end{array}$ & $\begin{array}{l}20 \mathrm{~b} \\
24 \mathrm{ab} \\
31 \mathrm{ab} \\
45 \mathrm{a}\end{array}$ & $\begin{array}{c}8 b \\
8 b \\
12 a b \\
19 a\end{array}$ & $\begin{array}{l}17 \mathrm{~b} \\
22 \mathrm{~b} \\
51 \mathrm{ab} \\
90 \mathrm{a}\end{array}$ & $\begin{array}{c}1987 \\
8 b \\
8 b \\
14 a b \\
19 a\end{array}$ & $\begin{array}{r}7 \mathrm{a} \\
10 \mathrm{a} \\
12 \mathrm{a} \\
18 \mathrm{a}\end{array}$ & $\begin{array}{c}785 b \\
896 a b \\
928 a b \\
1023 a\end{array}$ & $\begin{array}{l}13 a \\
14 a \\
15 a \\
15 a\end{array}$ & $\begin{array}{l}0.48 \mathrm{~b} \\
0.62 \mathrm{~b} \\
0.67 \mathrm{~b} \\
1.02 \mathrm{a}\end{array}$ & $\begin{array}{l}7.7 \mathrm{a} \\
7.6 \mathrm{ab} \\
7.5 \mathrm{ab} \\
7.2 \mathrm{~b}\end{array}$ \\
\hline $\begin{array}{c}0 \\
22.5 \\
45 \\
90\end{array}$ & $\begin{array}{r}4 a \\
5 a \\
7 a \\
14 a\end{array}$ & $\begin{array}{c}47 c \\
69 b c \\
81 b \\
119 a\end{array}$ & $\begin{array}{l}14 c \\
18 b c \\
28 b \\
38 a\end{array}$ & $\begin{array}{c}2 c \\
4 b c \\
7 b \\
13 a\end{array}$ & $\begin{array}{l}21 \mathrm{~b} \\
20 \mathrm{~b} \\
65 \mathrm{a} \\
77 \mathrm{a}\end{array}$ & $\begin{array}{c}1988 \\
6 \mathrm{~b} \\
5 \mathrm{~b} \\
9 \mathrm{ab} \\
18 \mathrm{a}\end{array}$ & $\begin{array}{r}8 a \\
11 a \\
7 a \\
13 a\end{array}$ & $\begin{array}{l}381 c \\
448 c \\
598 b \\
758 a\end{array}$ & $\begin{array}{l}13 c \\
15 c \\
18 b \\
24 a\end{array}$ & $\begin{array}{l}0.34 \mathrm{c} \\
0.48 \mathrm{bc} \\
0.64 \mathrm{ab} \\
0.83 \mathrm{a}\end{array}$ & $\begin{array}{l}7.9 \mathrm{a} \\
7.7 \mathrm{ab} \\
7.4 \mathrm{~b} \\
7.0 \mathrm{c}\end{array}$ \\
\hline
\end{tabular}

${ }_{1}^{1}$ Means within the same column and year followed by the same letter are not significantly different at the 0.05 level by Tukey's multiple range test. 
Table 3. Heavy and trace metals ( $\mathrm{mg} \mathrm{kg}^{-1}$ ) from an unamended and sewage sludge amended grassland soils.

\begin{tabular}{|c|c|c|c|c|c|c|c|c|}
\hline $\begin{array}{l}\text { Treatmen } \\
\left(\mathrm{Mg} \mathrm{ha}^{-1}\right)\end{array}$ & $\mathrm{Al}$ & B & $\mathrm{Cu}$ & $\mathrm{Cd}$ & $\mathrm{Fe}$ & $\mathbf{M n}$ & $\mathbf{P b}$ & $Z_{\text {II }}$ \\
\hline $\begin{array}{c}0 \\
22.5 \\
45 \\
90\end{array}$ & $\begin{array}{l}0.20 \mathrm{a}^{\prime} \\
0.20 \mathrm{a} \\
0.20 \mathrm{a} \\
0.20 \mathrm{a}\end{array}$ & $\begin{array}{l}0.06 \mathrm{a} \\
0.06 \mathrm{a} \\
0.07 \mathrm{a} \\
0.09 \mathrm{a}\end{array}$ & $\begin{array}{l}1.04 \mathrm{c} \\
1.19 \mathrm{bc} \\
1.60 \mathrm{ab} \\
2.10 \mathrm{a}\end{array}$ & $\begin{array}{l}0.01 \mathrm{a} \\
0.01 \mathrm{a} \\
0.01 \mathrm{a} \\
0.01 \mathrm{a}\end{array}$ & $\begin{array}{l}3.31 \mathrm{a} \\
3.22 \mathrm{a} \\
3.36 \mathrm{a} \\
3.47 \mathrm{a}\end{array}$ & $\begin{array}{l}3.46 \mathrm{~b} \\
4.21 \mathrm{ab} \\
5.32 \mathrm{ab} \\
6.10 \mathrm{a}\end{array}$ & $\begin{array}{l}0.55 a \\
0.60 a \\
0.58 a \\
0.60 a\end{array}$ & $\begin{array}{l}0.29 c \\
0.35 b c \\
0.61 a b \\
0.76 a\end{array}$ \\
\hline $\begin{array}{c}0 \\
22.5 \\
45 \\
90\end{array}$ & $\begin{array}{l}0.20 \mathrm{a} \\
0.20 \mathrm{a} \\
0.20 \mathrm{a} \\
0.23 \mathrm{a}\end{array}$ & $\begin{array}{l}0.07 \mathrm{a} \\
0.10 \mathrm{a} \\
0.10 \mathrm{a} \\
0.11 \mathrm{a}\end{array}$ & $\begin{array}{l}0.92 \mathrm{~b} \\
2.21 \mathrm{ab} \\
2.99 \mathrm{a} \\
3.48 \mathrm{a}\end{array}$ & $\begin{array}{l}0.01 \mathrm{a} \\
0.01 \mathrm{a} \\
0.02 \mathrm{a} \\
0.02 \mathrm{a}\end{array}$ & $\begin{array}{l}6 \\
3.33 a \\
3.94 a \\
4.32 a \\
4.41 a\end{array}$ & $\begin{array}{l}5.74 \mathrm{~b} \\
7.03 \mathrm{ab} \\
7.26 \mathrm{ab} \\
9.99 \mathrm{a}\end{array}$ & $\begin{array}{l}0.63 a \\
0.60 a \\
0.65 a \\
0.68 a\end{array}$ & $\begin{array}{l}0.27 \mathrm{~b} \\
0.79 \mathrm{ab} \\
1.01 \mathrm{ab} \\
1.20 \mathrm{a}\end{array}$ \\
\hline $\begin{array}{c}0 \\
22.5 \\
45 \\
90\end{array}$ & $\begin{array}{l}0.28 \mathrm{a} \\
0.30 \mathrm{a} \\
0.28 \mathrm{a} \\
0.23 \mathrm{a}\end{array}$ & $\begin{array}{l}0.04 \mathrm{~b} \\
0.05 \mathrm{ab} \\
0.07 \mathrm{ab} \\
0.09 \mathrm{a}\end{array}$ & $\begin{array}{l}1.76 \mathrm{~b} \\
2.16 \mathrm{ab} \\
4.49 \mathrm{a} \\
5.35 \mathrm{a}\end{array}$ & $\begin{array}{l}0.03 \mathrm{a} \\
0.03 \mathrm{a} \\
0.06 \mathrm{a} \\
0.06 \mathrm{a}\end{array}$ & $\begin{array}{l}3.47 \mathrm{a} \\
3.52 \mathrm{a} \\
4.93 \mathrm{a} \\
5.59 \mathrm{a}\end{array}$ & $\begin{array}{l}5.08 \mathrm{~b} \\
6.03 \mathrm{ab} \\
5.62 \mathrm{ab} \\
9.50 \mathrm{a}\end{array}$ & $\begin{array}{l}0.78 \mathrm{a} \\
0.83 \mathrm{a} \\
0.98 \mathrm{a} \\
0.95 \mathrm{a}\end{array}$ & $\begin{array}{l}0.50 \mathrm{~b} \\
0.77 \mathrm{ab} \\
1.62 \mathrm{ab} \\
1.72 \mathrm{a}\end{array}$ \\
\hline $\begin{array}{r}0 \\
22.5 \\
45 \\
90\end{array}$ & $\begin{array}{l}0.10 \mathrm{a} \\
0.10 \mathrm{a} \\
0.18 \mathrm{a} \\
0.23 \mathrm{a}\end{array}$ & $\begin{array}{l}0.05 c \\
0.07 \mathrm{c} \\
0.10 \mathrm{~b} \\
0.15 \mathrm{a}\end{array}$ & $\begin{array}{r}0.74 c \\
2.72 c \\
8.46 b \\
15.55 a\end{array}$ & $\begin{array}{l}0.01 c \\
0.03 c \\
0.08 b \\
0.14 a\end{array}$ & $\begin{array}{l}88 \\
2.51 \mathrm{c} \\
3.91 \mathrm{bc} \\
7.13 \mathrm{~b} \\
10.94 \mathrm{a}\end{array}$ & $\begin{array}{r}4.42 \mathrm{~b} \\
5.44 \mathrm{~b} \\
6.58 \mathrm{~b} \\
10.80 \mathrm{a}\end{array}$ & $\begin{array}{l}0.61 \mathrm{c} \\
0.73 \mathrm{bc} \\
1.03 \mathrm{~b} \\
1.45 \mathrm{a}\end{array}$ & $\begin{array}{l}0.10 c \\
1.00 c \\
3.57 b \\
6.84 a\end{array}$ \\
\hline
\end{tabular}

${ }^{1}$ Means within the same column and year followed by the same letter are not significantly different at the 0.05 level by Tukey's multiple range test.

water extractable boron (B), were determined using the DTPA (diethylenetriaminepentaacetic acid) method (AOAC 1980).

Plant species density and foliar cover were determined using Community Structure Analysis (CSA) (Pase 1981, Francis 1986). In each of the 16 treatment plots, one hundred $5 \times 10-\mathrm{cm}$ rated microplots (Morris 1973) for foliar cover and ten $0.5 \mathrm{~m}^{2}$ circular plots for density were measured along a $15.25 \mathrm{~m}$ permanent transect. Sod-formers, such as blue grama, were counted as individual viable units each time a break within the crown was observed. Each transect was read in August of 1985 through 1988. Diversity indices were calculated using Shannon's index of species diversity (GreigSmith 1983).

Herbaceous plant production by species was determined at the end of the growing season in late September from 1985-1988. In each of the 16 treatment plots, 10 subplots were randomly selected for double sampling (Wilm et al. 1944). All 10 subplots were ocularly estimated using a $0.3 \times 0.6-\mathrm{m}$ quadrat; 5 quadrats were harvested, oven dried at $70^{\circ} \mathrm{C}$ for 48 hours, and weighed. The 5 harvested samples and 10 estimated subplots were used to estimate herbaceous production of each species by regession analysis.

Variations in the soil chemical properties, plant species density, richness, diversity, foliar cover, and herbaceous production among the unamended and amended treatments for each treatment year were analyzed using a one-way analysis of variance at the $5 \%$ probability level. Orthogonal polynomials were used to characterize the relationships of soil chemical properties and vegetation parameters among sewage sludge application rates, at the $5 \%$ probability level. Also, Tukey's multiple range test was used to aid interpretation of polynomial relationships.

\section{Results and Discussion}

\section{Soil Properties}

In the first growing season (1985), soil N, P, and potassium (K) increased linearly following the application of sewage sludge (Table 2). With the exception of $\mathrm{OM}$ and $\mathrm{pH}$, all other soil chemical properties, including electrical conductivity (EC), were significantly higher in the $90 \mathrm{Mg}^{-1}$ sludge treatment than in the untreated soil. With the application of sludge, EC increased linearly from 0.36 in the unamended soil to $2.23 \mathrm{dS} \mathrm{m}^{-1}$ in the $90 \mathrm{Mg}$ $\mathrm{ha}^{-1}$ sludge treatment. Normally, EC levels above $2.0 \mathrm{dS} \mathrm{m}^{-1}$ inhibit plant growth (Bohn et al. 1979). However, the EC levels in the 90 $\mathrm{Mg} \mathrm{ha}^{-1}$ sludge treatment decreased to 1.97 after 2 growing seasons and to $0.83 \mathrm{dS} \mathrm{m}^{-1}$ after 4 growing seasons. The light and interme- diate sludge treatments had EC levels well below $2.0 \mathrm{dS} \mathrm{m}^{-1}$ and will probably not affect plant growth.

Soil $O M$ contents exhibited a quadratic polynomial response to sludge application rates during the first and second growing seasons, peaking in the low and intermediate sludge treatments and decreasing in concentration at the sludge treatment applied at the highest rate. The levels of $O M$ finally increased linearly with sludge amendment after 4 growing seasons. At that time, the 45 and $90 \mathrm{Mg}$ $\mathrm{ha}^{-1}$ sludge treatments had OM contents significantly higher than the unamended soil.

The only soil property that decreased linearly with the application of sludge was $\mathrm{pH}$ (Table 2). In the first growing season, soil $\mathrm{pH}$ decreased significantly from 7.8 to 7.5 , and even further in the third and fourth growing seasons to 7.2 and 7.0, respectively. Albuquerque sludge had a pH of 6.8, a full pH unit lower than the soil receiving treatment (Table 1 ). The decrease in soil $\mathrm{pH}$ was probably due to leachates from this slightly acidic sludge, as well as to acid-producing microbial reactions in the soil (Miller 1973).

Soil chemical properties like N, P, and $K$ after the second growing season had similar responses to the application of sludge, as in 1985. Again, all soil chemical properties, except $\mathrm{OM}$ and $\mathbf{p H}$, responded linearly with the application of sludge. Soil $P$ and total Kjeldahl nitrogen (TKN) even increased at a higher rate in the second growing season than in the first, while most other soil chemical properties remained at the same levels or declined slightly after rapid first-year increases. These soil properties, however, remained significantly elevated related to the control, especially in the 45 and $90 \mathrm{Mg} \mathrm{ha}^{-1}$ sludge treatment rates. After the third and fourth growing seasons, most soil chemical properties remained significantly elevated in the sludge-amended soils than in the unamended soil, but not as high as in the first and second growing seasons.

Levels of DTPA soil cadium (Cd) and lead (Pb) did not significantly increase as a result of sludge amendment after the first 3 growing seasons (Table 3), and did not significantly accumulate in plant tissue collected from blue grama, galleta, or bottlebrush squirreltail (Fresquez et al. 1990). However, the concentrations of $\mathrm{Cd}$ and $\mathrm{Pb}$ after 4 growing seasons were significantly higher in the 45 and $90 \mathrm{Mg} \mathrm{ha}^{-1}$ sludge treatment compared to that in the unamended soil and were probably due to the decrease in $\mathrm{pH}$ from 7.9 to 7.0. Generally, heavy metals begin to solubilize when the $\mathrm{pH}$ approaches 7.0 (Bohn et al. 1979). Although levels of soil Cd and $\mathrm{Pb}$ increased to 0.14 and $1.45 \mathrm{mg} \mathrm{kg}^{-1}$, respectively, in the $90 \mathrm{Mg}$ 
Table 4. Plant density, species richness and diversity from an unamended and sewage sludge amended (Mg ha-1) grassland soil after four growing seasons. ${ }^{1}$

\begin{tabular}{|c|c|c|c|c|c|c|c|c|c|c|c|c|c|c|c|c|}
\hline \multirow[b]{2}{*}{ Species } & \multicolumn{4}{|c|}{1985} & \multicolumn{4}{|c|}{1986} & \multicolumn{4}{|c|}{1987} & \multicolumn{4}{|c|}{1988} \\
\hline & $\overline{0}$ & 22.5 & 45 & 90 & 0 & 22.5 & 45 & 90 & 0 & 22.5 & 45 & 90 & 0 & 22.5 & 45 & 90 \\
\hline $\begin{array}{l}\text { GRASSES } \\
\text { Blue grama } \\
\text { Bouteloua gracilis (H.B.K) Lag ex Ste }\end{array}$ & $\begin{array}{l}4.5 \\
\text { eud) }\end{array}$ & 4.9 & 5.4 & 5.5 & 3.7 & 3.9 & 4.1 & 4.7 & 3.7 & 3.8 & 3.6 & 4.1 & 3.9 & 4.3 & 4.4 & 5.0 \\
\hline $\begin{array}{l}\text { Galleta } \\
\text { (Hilaria jamesii (Torr.) Benth.) }\end{array}$ & 5.8 & 4.6 & 4.8 & 5.6 & 4.8 & 2.0 & 1.6 & 3.0 & 3.0 & 1.5 & 1.2 & 2.3 & 2.1 & 1.2 & 1.5 & 2.6 \\
\hline $\begin{array}{l}\text { Bottlebrush squirreltail } \\
\text { (Sitanion hystrix (Nut.) J.G. Sm) }\end{array}$ & 2.5 & 0.9 & 2.0 & 0.7 & 2.9 & 3.2 & 4.3 & 3.9 & 2.9 & 2.9 & 2.3 & 1.9 & 1.0 & 0.6 & 0.5 & 0.5 \\
\hline Total grasses & 16.0 & 13.3 & 14.5 & 13.5 & 14.1 & 11.8 & 12.1 & 13.0 & 13.3 & 9.4 & 8.3 & 9.5 & 9.4 & 7.7 & 8.3 & 9.1 \\
\hline $\begin{array}{l}\text { FORBS } \\
\text { Baby white aster } \\
\text { (Leucelene ericoides (Torr.) Greene) }\end{array}$ & 0.3 & 0.5 & 0.0 & 0.0 & .0 & 0.3 & 0.0 & 0.0 & 0.3 & 0.4 & 0.1 & .0 & 0.1 & .0 & 0.0 & 0.0 \\
\hline $\begin{array}{l}\text { (pennate) groundsel } \\
\text { (Senecio multilobatus T. + G.) }\end{array}$ & 0.2 & 0.0 & 0.0 & 0.0 & 0.1 & 0.0 & 0.0 & 0.0 & 0.0 & 0.0 & 0.0 & 0.0 & 0.0 & 0.0 & 0.0 & 0.0 \\
\hline $\begin{array}{l}\text { Scarlet globemallow } \\
\text { (Sphaeralcea coccinea (Pursh.) Rydb.) }\end{array}$ & 0.3 & 0.2 & 0.1 & 0.0 & 0.3 & 0.1 & 0.1 & 0.0 & 0.4 & 0.1 & .0 & .0 & 0.3 & 0.1 & .0 & .0 \\
\hline Tobal forbs & 1.2 & 1.0 & 0.3 & 0.1 & 0.8 & 0.4 & 0.1 & 0.0 & 0.8 & 0.9 & 0.4 & 0.6 & 0.4 & 0.2 & 0.1 & 0.1 \\
\hline $\begin{array}{l}\text { SHRUBS } \\
\text { Fourwing saltbush } \\
\text { (Atriplex canesens (Pursh.) Nutt.) }\end{array}$ & 0.0 & 0.0 & 0.0 & 0.0 & 0.0 & 0.0 & 0.0 & 0.0 & 0.0 & 0.3 & 0.4 & 0.1 & 0.0 & 0.0 & 0.0 & 0.0 \\
\hline $\begin{array}{l}\text { Winterfat } \\
\text { (Eurotia lanata (Pursh.) Mog.) }\end{array}$ & 0.0 & 0.0 & 0.0 & 0.0 & 0.0 & 0.0 & 0.0 & 0.0 & 0.0 & 0.0 & 0.0 & 0.0 & 0.0 & 0.0 & 0.0 & 0.0 \\
\hline $\begin{array}{l}\text { Broom snakeweed } \\
\text { (Gutierrezia sarothrae (Pursh.) Gritt. }\end{array}$ & $\begin{aligned} & 3.9 \\
+ & \text { Rusb }\end{aligned}$ & 2.0 & 1.8 & 1.0 & 3.4 & 2.0 & 1.5 & 1.0 & 3.5 & 1.5 & 1.2 & 1.0 & 2.7 & 0.1 & 0.0 & .0 \\
\hline Total shrubs & 3.9 & 2.0 & 2.0 & 1.0 & 3.4 & 2.0 & 1.6 & 1.0 & 3.5 & 1.8 & 1.6 & 1.4 & 2.7 & 0.2 & 0.2 & 0.0 \\
\hline $\begin{array}{l}\text { Total density } \\
\text { Total richness } \\
\text { Diversity }\end{array}$ & $\begin{array}{l}20.9 \mathrm{a}^{2} \\
16 \mathrm{a} \\
1.8 \mathrm{a}\end{array}$ & $\begin{array}{l}16.2 \mathrm{a} \\
16 \mathrm{a} \\
1.6 \mathrm{ab}\end{array}$ & $\begin{array}{l}16.6 \mathrm{a} \\
14 \mathrm{ab} \\
1.6 \mathrm{ab}\end{array}$ & $\begin{array}{l}14.6 \mathrm{a} \\
10 \mathrm{~b} \\
1.3 \mathrm{~b}\end{array}$ & $\begin{array}{l}18.2 \mathrm{a} \\
14 \mathrm{a} \\
1.8 \mathrm{a}\end{array}$ & $\begin{array}{l}14.2 \mathrm{a} \\
11 \mathrm{a} \\
1.7 \mathrm{ab}\end{array}$ & $\begin{array}{l}13.7 \mathrm{a} \\
11 \mathrm{a} \\
1.6 \mathrm{ab}\end{array}$ & $\begin{array}{l}14.1 \mathrm{a} \\
10 \mathrm{a} \\
1.4 \mathrm{~b}\end{array}$ & $\begin{array}{l}18.0 \mathrm{a} \\
13 \mathrm{a} \\
1.7 \mathrm{a}\end{array}$ & $\begin{array}{l}11.8 \mathrm{~b} \\
16 \mathrm{a} \\
1.8 \mathrm{a}\end{array}$ & $\begin{array}{l}10.2 \mathrm{~b} \\
14 \mathrm{a} \\
1.8 \mathrm{a}\end{array}$ & $\begin{array}{l}11.5 \mathrm{~b} \\
14 \mathrm{a} \\
1.6 \mathrm{a}\end{array}$ & $\begin{array}{l}12.5 \mathrm{a} \\
11 \mathrm{a} \\
1.6 \mathrm{a}\end{array}$ & $\begin{array}{l}8.0 \mathrm{~b} \\
14 \mathrm{a} \\
1.3 \mathrm{ab}\end{array}$ & $\begin{array}{l}8.5 \mathrm{~b} \\
11 \mathrm{a} \\
1.4 \mathrm{ab}\end{array}$ & $\begin{array}{l}9.1 \mathrm{~b} \\
9 \mathrm{a} \\
1.1 \mathrm{~b}\end{array}$ \\
\hline
\end{tabular}

IDensity values that equal 0.0 contain no plants; values the equal .0 contains less than 0.05 plants per $0.5 \mathrm{~m}^{2}$.

2Means within the same row and year followed by the same letter are not significantly different at the 0.05 level by Tukey's multiple range test.

$\mathrm{ha}^{-1}$ sludge treatment after 4 growing seasons, the levels were still far below phytotoxic concentrations $\left(1.0\right.$ and $20 \mathrm{mg} \mathrm{kg}^{-1}$, respectively) (Schafer 1979, Tiedemann, and Lopez 1982). However, Cd concentrations $\left(0.14 \mathrm{mg} \mathrm{kg}^{-1}\right)$ in the $90 \mathrm{Mg} \mathrm{ha}^{-1}$ sludge treatment were just above maximum acceptable soil standards $\left(\theta .10 \mathrm{mg} \mathrm{kg}^{-1}\right)$. Therefore, based on the amount of $\mathrm{Cd}$ in the pretreatment sludge, $64 \mathrm{Mg} \mathrm{ha}^{-1}$ of sludge can be safely applied to this soil without apparent short-term phytotoxic effects.

The levels of other trace elements, such as DTPA soil copper $(\mathrm{Cu})$, manganese $(\mathrm{Mn})$, and zinc $(\mathrm{Zn})$, increased linearly with sludge amendment during the first growing season. At that time, both the 45 and $90 \mathrm{Mg} \mathrm{ha}^{-1}$ sludge treatments contained significantly higher concentrations of $\mathrm{Cu}$ and $\mathrm{Zn}$ than the control. After 2 growing seasons, soil $\mathrm{Cu}, \mathrm{Mn}$, and $\mathrm{Zn}$ increased linearly with the application of sludge and the levels of soil $B$ and DTPA soil $\mathbf{C u}$, $\mathrm{Mn}$, and $\mathrm{Zn}$ increased linearly with amendment after 3 growing seasons. After 4 growing seasons, the levels of soil $\mathrm{B}, \mathrm{Cu}$, iron $(\mathrm{Fe})$, $\mathrm{Mn}$, and $\mathrm{Zn}$ increased linearly with the application of sludge. Most of these micronutrients after 4 growing seasons were significantly higher in the 45 and $90 \mathrm{Mg} \mathrm{ha}^{-1}$ sludge treatments than in the control soil. These increases in micronutrient levels after 4 growing seasons were probably a result of an increase in the decomposition and incorporation of the sludge, but also to the significant decrease in soil $\mathrm{pH}$ from 7.9 to 7.0 , which may have partially solubilized these elements.

While soil aluminum (Al), B, Fe, and $\mathrm{Zn}$ levels in the $90 \mathrm{Mg} \mathrm{ha}^{-1}$ sludge treatment were all within acceptable levels commonly found in other soils, the level of $\mathrm{Cu}\left(15.55 \mathrm{mg} \mathrm{kg}^{-1}\right)$ and $\mathrm{Mn}(10.80 \mathrm{mg}$ $\mathrm{kg}^{-1}$ ) were slightly above the maximum acceptable standards (Schafer 1979, Tiedemann and Lopez 1982). Although soil Cu and Mn concentrations were far below phytotoxic levels ( 40 and $60 \mathrm{mg}$ $\mathrm{kg}^{-1}$, respectively), the maximum acceptable standards for both $\mathrm{Cu}$ and $\mathrm{Mn}$ that can be safely added to soils is $10 \mathrm{mg} \mathrm{kg}^{-1}$. Therefore, the total possible amount of treated sludge that can be added as an amendment before reaching unacceptable soil $\mathrm{Cu}$ and $\mathrm{Mn}$ levels are 62 and $60 \mathrm{Mg} \mathrm{ha}^{-1}$, respectively.

\section{Vegetation Properties}

Increased soil fertility through nutrient enrichment may change the plant community structure. Normally, in the presence of a stimulus, plant production increases, while the diversity of plant species decreases (Houston 1979, Biondini, and Redente 1986). The dominant plant species in this study prior to soil amendment were broom snakeweed, blue grama, and galleta. Following the application of sewage sludge, fendler three awn (Aristida fendleriana Stued.), ring muhly (Muhlenbergia torreyi (Kunth) Hitchc.), bottlebrush squirreltail (Sitanion hystrix (Nutt.) J.G. Smith), and especially broom snakeweed decreased in density with increasing sludge rates after the first growing season (Table 4). Blue grama density did not change with sludge amendment.

Since the amount of water tends to limit the density of plants, and the amount of $\mathrm{N}$ usually regulates the size of a plant in the semiarid Southwest (Ludwig et al. 1989), the rapid growth of blue grama in the sludge amended soils (Table 6) may have resulted in a competitive effect that reduced the density of other plant species. For example, total plant density decreased linearly from 20.9 in the control plots to 14.6 plants per $0.5 \mathrm{~m}^{2}$ in the $90 \mathrm{Mg} \mathrm{ha}^{-1}$ sludge treatment after the first growing season (Table 4). Similarly, the number of plant species decreased linearly from 16 in the control treatment to 10 in the $90 \mathrm{Mg} \mathrm{ha}^{-1}$ sludge treatment. Thus, species diversity decreased linearly from 1.8 in the control to 1.3 in the 90 $\mathrm{Mg} \mathrm{ha}^{-1}$ sludge treatment as the density of plants and the number of 
Table 5. Major species and total foliar cover (\%) from an unamended and sewage sludge amended grassland soils.

\begin{tabular}{|c|c|c|c|c|c|}
\hline \multirow[b]{2}{*}{$\begin{array}{l}\text { Treatment } \\
\left(\mathbf{M g ~ h a} \mathbf{~}^{-1}\right)\end{array}$} & \multicolumn{4}{|c|}{ Species! } & \multirow[b]{2}{*}{ Total $^{2}$} \\
\hline & $\begin{array}{c}\text { Broom } \\
\text { snakeweed }\end{array}$ & $\begin{array}{c}\text { Blue } \\
\text { grama }\end{array}$ & Galleta & $\begin{array}{l}\text { Bottlebrush } \\
\text { squirreltail }\end{array}$ & \\
\hline $\begin{array}{c}0 \\
22.5 \\
45 \\
90\end{array}$ & $\begin{array}{l}6 a^{3} \\
5 a \\
4 a \\
3 a\end{array}$ & $\begin{array}{l}16 b \\
25 b \\
23 b \\
27 a\end{array}$ & $\begin{array}{l}1985 \\
2.4 \mathrm{a} \\
1.9 \mathrm{a} \\
3.4 \mathrm{a} \\
3.7 \mathrm{a}\end{array}$ & $\begin{array}{l}1.2 \mathrm{ab} \\
1.1 \mathrm{ab} \\
2.0 \mathrm{a} \\
0.3 \mathrm{~b}\end{array}$ & $\begin{array}{l}30 \mathrm{~b} \\
37 \mathrm{a} \\
35 \mathrm{ab} \\
36 \mathrm{ab}\end{array}$ \\
\hline $\begin{array}{c}0 \\
22.5 \\
45 \\
90\end{array}$ & $\begin{array}{l}9 a \\
9 a \\
5 a \\
4 a\end{array}$ & $\begin{array}{c}18 b \\
35 a b \\
34 a b \\
40 a\end{array}$ & $\begin{array}{l}1986 \\
2.2 \mathrm{a} \\
1.2 \mathrm{a} \\
0.8 \mathrm{a} \\
3.2 \mathrm{a}\end{array}$ & $\begin{array}{l}1.5 \mathrm{~b} \\
3.1 \mathrm{~b} \\
8.1 \mathrm{a} \\
4.7 \mathrm{ab}\end{array}$ & $\begin{array}{l}35 b \\
54 a \\
52 a \\
55 a\end{array}$ \\
\hline $\begin{array}{c}0 \\
22.5 \\
45 \\
90\end{array}$ & $\begin{array}{r}8 b \\
16 a \\
9 b \\
3 b\end{array}$ & $\begin{array}{l}17 b \\
21 b \\
21 b \\
24 a\end{array}$ & $\begin{array}{l}1987 \\
1.7 \mathrm{a} \\
0.6 \mathrm{a} \\
0.9 \mathrm{a} \\
2.1 \mathrm{a}\end{array}$ & $\begin{array}{l}1.4 \mathrm{a} \\
2.3 \mathrm{a} \\
4.0 \mathrm{a} \\
2.2 \mathrm{a}\end{array}$ & $\begin{array}{l}31 b \\
42 a \\
37 a b \\
35 a b\end{array}$ \\
\hline $\begin{array}{c}0 \\
22.5 \\
45 \\
90\end{array}$ & $\begin{array}{l}4 \mathrm{a} \\
0 \mathrm{~b} \\
0 \mathrm{~b} \\
0 \mathrm{~b}\end{array}$ & $\begin{array}{l}17 b \\
23 b \\
23 b \\
27 a\end{array}$ & $\begin{array}{l}1988 \\
0.8 \mathrm{a} \\
0.6 \mathrm{a} \\
1.0 \mathrm{a} \\
2.2 \mathrm{a}\end{array}$ & $\begin{array}{l}0.7 \mathrm{a} \\
0.4 \mathrm{a} \\
1.2 \mathrm{a} \\
0.7 \mathrm{a}\end{array}$ & $\begin{array}{l}25 b \\
28 b \\
28 b \\
32 a\end{array}$ \\
\hline
\end{tabular}

'Broom snakeweed (Gutierrezia sarothrae), Blue grama (Bouteloua gracilis), Galleta (Hilaria jamesii) and Bottlebrush squirreltail (Sitanion hystrix).

IIncludes cover from all species.

${ }^{3}$ Means within the same column and year followed by the same letter are not significantly different at the 0.05 level by Tukey's multiple range test.

plant species decreased. These results are consistent with the resource-ratio hypothesis of Tilman (1982), who suggested that species with optimal growth at higher nutrient levels grow rapidly and out-compete other species. The density and diversity of plant species were still significantly decreased with sludge amendment in the fourth growing season. This decrease may have been due to an increase in sludge decomposition and incorporation of $\mathrm{OM}$ in the amended soils, resulting in an increase in plant available $\mathbf{N}$ (Table 2).

Broom snakeweed density decreased linearly with the amount of sewage sludge after the first growing season from 3.9 in the unamended control to $2.0,1.8$, and 1.0 plants per $0.5 \mathrm{~m}^{-2}$ in the light, intermediate, and heavy sludge treatments, respectively. The 45 and the $90 \mathrm{Mg} \mathrm{ha}^{-1}$ sludge treatments contained significantly $(P<0.05)$ fewer snakeweed plants than the control. This dramatic decrease in the density of broom snakeweed with increasing sludge rates in the first growing season may have been due to a number or combination of factors (i.e., pH, EC, and $\mathrm{N}$ levels). However, with respect to $\mathrm{N}$ levels and root morphology, a study conducted in the Chihahuan desert concluded that shallower-rooted perennial grasses extracted the majority of surface-applied $\mathbf{N}$ as it moved down through the soil horizon before deeper taprooted shrubs could utilize the available N (Ettershank et al. 1978). Blue grama plants have approximately $85 \%$ of their functional root biomass concentrated in the upper $20 \mathrm{~cm}$ of the soil (Singh and Coleman 1977). Also, blue grama contains greater amounts of young nonsuberized roots (so important in water and nutrient absorption) in the upper soil profile in semiarid grasslands (Ares 1976) than in tallgrass prairie (Hayes and Seastedt 1987). Conversely, broom snakeweed plants have a deeper root system with well-developed tap and lateral roots (McDaniel et al. 1982). Therefore, with the application of sewage sludge, nutrients like $\mathbf{N}$ were first available in the upper few centimeters of the soil surface. Under these conditions, blue grama plants may have been in a better position, morphologically, to utilize these soil surface nutrients and effective soil moisture before snakeweed could respond. Although tissue $\mathbf{N}$ contents were not analyzed for snakeweed, $\mathrm{N}$ in the tissue of blue grama from these same sludge-amended soils was significantly higher than from plants growing in the control after the first growing season (Fresquez et al. 1990).

Those few snakeweed plants that survived the first growing season following sludge amendment responded positively to the added nutrients by increasing in foliar cover and yield over the next 2 growing seasons (Table 5 and 6). In other words, the cover and yield of individual snakeweed plants increased as their density decreased with sludge amendment. Apparently, after the second and third growing seasons, sufficient quantities of nutrients from the sludge-amendment may have leached down to a soil zone where they were now available for broom snakeweed utilization. However, after 4 growing seasons nearly all of the snakeweed plants in the sludge amended treatments had died. Mature broom snakeweed plants in the control treatment also appeared to be senescing rapidly. For example, broom snakeweed in the control treatment decreased from 3.5 plants per $0.5 \mathrm{~m}^{2}, 8 \%$ cover, and $229 \mathrm{~kg} \mathrm{ha}^{-1}$ of herbage in the third growing season to 2.7 plants per $0.5 \mathrm{~m}^{2}, 4 \%$ cover, and $72 \mathrm{~kg} \mathrm{ha}^{-1}$ herbage in the fourth growing season (Tables 4,5 , and 6 ).

Since broom snakeweed populations tend to be even aged and cyclic in nature (McDaniel et al. 1984), the increased soil fertility provided by sludge may have accelerated broom snakeweed growth to the point where it may have matured just ahead of plants in the control treatment. At that point, broom snakeweed plants in the sludge treatments may have been in a more weakened condition than plants in the control treatment, allowing shallow-rooted plants such as blue grama to fully outcompete broom snakeweed for water. In fact, a visual observation in the early growing season of 1989 (just prior to the fifth growing season) showed that broom

Table 6. Herbaceous production ( $\mathrm{kg} \mathrm{ha}^{-1}$ ) from an unamended and sewage sludge amended grassland soils.

\begin{tabular}{|c|c|c|c|c|c|}
\hline \multirow[b]{2}{*}{$\begin{array}{l}\text { Treatment } \\
\left(\mathrm{Mg} \mathrm{ha}^{-1}\right)\end{array}$} & \multicolumn{4}{|c|}{ Species ${ }^{1}$} & \multirow[b]{2}{*}{ Total ${ }^{2}$} \\
\hline & $\begin{array}{l}\text { Broom } \\
\text { snakeweed }\end{array}$ & $\begin{array}{c}\text { Blue } \\
\text { grama }\end{array}$ & Galleta & $\begin{array}{l}\text { Bottlebrush } \\
\text { squirreltail }\end{array}$ & \\
\hline $\begin{array}{c}0 \\
22.5 \\
45 \\
90\end{array}$ & $\begin{array}{l}194 a^{3} \\
214 a \\
237 a \\
94 a\end{array}$ & $\begin{array}{l}270 b \\
480 a b \\
433 a b \\
509 a\end{array}$ & $\begin{array}{c}1985 \\
48 b \\
79 a b \\
100 a \\
103 a\end{array}$ & $\begin{array}{l}34 a \\
20 a \\
35 a \\
25 a\end{array}$ & $\begin{array}{l}654 b \\
872 a b \\
914 a \\
825 b\end{array}$ \\
\hline $\begin{array}{c}0 \\
22.5 \\
45 \\
90\end{array}$ & $\begin{array}{l}460 a \\
525 a \\
259 a \\
192 a\end{array}$ & $\begin{array}{c}392 \mathrm{~b} \\
575 \mathrm{ab} \\
824 \mathrm{ab} \\
1067 \mathrm{a}\end{array}$ & $\begin{array}{l}1986 \\
50 a \\
52 a \\
45 a \\
49 a\end{array}$ & $\begin{array}{r}90 a \\
99 a \\
147 a \\
123 a\end{array}$ & $\begin{array}{l}1208 \mathrm{~b} \\
1455 \mathrm{ab} \\
1417 \mathrm{ab} \\
1535 \mathrm{a}\end{array}$ \\
\hline $\begin{array}{c}0 \\
22.5 \\
45 \\
90\end{array}$ & $\begin{array}{l}229 a \\
323 a \\
324 a \\
184 a\end{array}$ & $\begin{array}{l}290 \mathrm{~b} \\
397 \mathrm{ab} \\
479 \mathrm{ab} \\
587 \mathrm{a}\end{array}$ & $\begin{array}{l}1987 \\
43 b \\
24 b \\
49 a b \\
68 a\end{array}$ & $\begin{array}{l}54 a \\
92 a \\
65 a \\
95 a\end{array}$ & $\begin{array}{l}795 \mathrm{~b} \\
1020 \mathrm{ab} \\
1129 \mathrm{a} \\
1008 \mathrm{ab}\end{array}$ \\
\hline $\begin{array}{c}0 \\
22.5 \\
45 \\
90\end{array}$ & $\begin{array}{r}72 \mathrm{a} \\
0 \mathrm{~b} \\
0 \mathrm{~b} \\
0 \mathrm{~b}\end{array}$ & $\begin{array}{l}231 \mathrm{~b} \\
366 \mathrm{ab} \\
561 \mathrm{a} \\
535 \mathrm{a}\end{array}$ & $\begin{array}{l}1988 \\
26 a \\
34 a \\
52 a \\
52 a\end{array}$ & $\begin{array}{r}8 a \\
9 a \\
5 a \\
16 a\end{array}$ & $\begin{array}{l}417 \mathrm{~b} \\
570 \mathrm{ab} \\
728 \mathrm{a} \\
716 \mathrm{a}\end{array}$ \\
\hline
\end{tabular}

'Broom snakeweed (Gutierrezia sarothrae), Blue grama (Bouteloua gracilis), Galleta (Hilaria jamesii) and Bottlebrush squirreltail (Sitanion hystrix).

2Includes production from all herbaceous species.

${ }^{3}$ Means within the same column and year followed by the same letter are not significantly different at the 0.05 level by Tukey's multiple range test. 
snakeweed was completely dead in all of the sludge treatments, while plants in the control treatment had vegetative regrowth. Thus, if broom snakeweed can be partially reduced after only 1 full growing season and completely eliminated after 5 growing seasons with a surface application of a slow-release organic fertilizer, sludge amendment could prove to be a very useful range management strategy for broom snakeweed/blue grama dominated plant communities. Broom snakeweed, a toxic, nonpalatable, competitive range weed (half-shrub), presently occupies over 16 million hectares in New Mexico, including over $62 \%$ of the State's grazing area (Budd 1989).

Total percent foliar cover in the first growing season significantly increased in all of the sludge treatments compared to the unamended control (Table 5). Blue grama increased linearly with the application of sludge and comprised nearly $70 \%$ of the total foliar cover. After the second growing season, total percent foliar cover increased linearly from $35 \%$ in the control soil to over $50 \%$ in the sludge-amended soils. Blue grama cover increased linearly with the sludge amendment, and doubled in the $90 \mathrm{Mg} \mathrm{ha}^{-1}$ sludge treatment as compared to the unamended control. Total plant cover and blue grama cover decreased in the next 2 years (third and fourth growing seasons). Both total and blue grama cover, however, were still significantly higher in the $90 \mathrm{Mg} \mathrm{ha}^{-1}$ sludge treatment than in the unamended control. Broom snakeweed had significantly higher foliar cover in the light sludge treatment compared to the unamended control during the third growing season. Although, snakeweed generally had greater amounts of foliar cover in the sludge treatments after the third growing season, it was from fewer snakeweed plants ( 1.5 per $0.5 \mathrm{~m}^{2}$ ) relative to those in the control treatment ( 3.5 per $\left.0.5 \mathrm{~m}^{2}\right)$. By the end of the fourth growing season, there were essentially no snakeweed plants in any of the sludge treatments.

Total herbaceous production after the first growing season exhibited a quadratic polynomial response to the application of sewage sludge, with the low and intermediate sludge treatments producing significantly higher plant yields than the unamended or the heaviest sludge treatment (Table 6). Although the $90 \mathrm{Mg} \mathrm{ha}^{-1}$ sludge treatment produced plant yields $171 \mathrm{~kg} \mathrm{ha}^{-1}$ higher than the control, the high salt levels associated with this sludge treatment may have partially limited plant yields, at least as compared to the other sludge treatments.

Blue grama yields increased linearly as a result of sludge amendment, and nearly doubled in weight from $\mathbf{2 7 0}$ in the control treatment to $509 \mathrm{~kg} \mathrm{ha}^{-1}$ in the sludge treatment applied at the highest rate. Blue grama has been shown to respond positively to $\mathbf{N}$ fertilization (Dwyer 1971, Pieper et al. 1973) and in our study soil N also increased linearly from sludge application (Table 2), which correlated well with the increase in blue grama yields.

Total herbaceous production after the second growing season, nearly doubled compared with the first growing season. The increase in herbaceous production in the second growing season in all of the treatments, including the control, was probably due to the exclusion of livestock grazing and to a $63 \%$ increase in the seasonal precipitation from 147 in 1985 to $239 \mathrm{~mm}$ in 1986. However, there were still significantly higher total plant yields recorded in the sludge-amended soils than in the unamended control treatment, which can probably be directly attributed to the higher fertility status of the soil. Once again, blue grama yields increased linearly with increasing sludge rates, but this time yields were almost 3 times higher than yields in the control treatment. Both increased soil $\mathrm{N}$ levels from sludge amendment and increased precipitation undoubtly favored the growth of blue grama.

Total herbaceous production from the third and fourth growing seasons followed the same general trend as in the first 2 growing seasons, with increased plant production from the sludge amended soils over those in the control. Sludge treatments resulted in essentially no broom snakeweed growth after the fourth growing season (Table 6). Many studies have shown that the complete elimination of broom snakeweed plants resulted in significantly higher yields of perennial grasses, particularly blue grama (Jameson 1966, Gesink et al. 1973, McDaniel et al, 1982). Our study had similar results, with blue grama yields increasing as broom snakeweed plants decreased. However, the short-term increase in blue grama yields were attributed more to an increase in soil fertility than to a reduction of broom snakeweed plants.

\section{Conclusions}

The application of sewage sludge to a degraded semiarid grassland, which was initially dominated by broom snakeweed and blue grama, significantly increased plant nutrients $\mathrm{N}, \mathrm{P}$, and $\mathrm{K}$, and micronutrients $\mathrm{Cu}, \mathrm{Fe}, \mathrm{Mn}$, and $\mathrm{Zn}$ over an unamended soil. Soil heavy metals were not significantly increased with sludge amendment, except in the fourth growing season when the soil $\mathrm{pH}$ decreased from 7.9 to 7.0 in the $90 \mathrm{Mg} \mathrm{ha}^{-1}$ sludge treatment. This sharp drop in soil pH apparently caused some solubility of soil $\mathrm{Cu}$, $\mathrm{Cd}$, and $\mathrm{Mn}$. Even though these elements increased, they were far from phytotoxic levels, and were only slightly above levels considered to be unacceptable.

Although, sludge amendment decreased total plant density, species richness, and diversity, blue grama cover and yield increased significantly while the density of broom snakeweed plants decreased. The near complete elimination of snakeweed after 4 growing seasons and the increase in blue grama cover and production as a result of sludge amendment may help to control and/or hinder the reestablishment of snakeweed plants.

Total plant foliar cover generally increased linearly with the application of sludge, while total herbaceous production peaked at the low and intermediate sludge rates. Blue grama responded most significantly to the application of sludge, by increasing in yields 2 to 3 fold over plants growing in the unamended control. The application of sewage sludge from 22.5 to $45 \mathrm{Mg} \mathrm{ha}^{-1}$ produced the most favorable soil and vegetation results.

This study showed that sewage sludge from a nonindustrial city such as Albuquerque can be safely applied to a degraded grassland in the semiarid Southwest without any apparent adverse environmental effects at sludge rates up to $45 \mathrm{Mg} \mathrm{ha}^{-1}$. Sewage sludge applied at $90 \mathrm{Mg} \mathrm{ha}^{-1}$ did not significantly increase plant yields over those obtained at lower sludge rates. Also, some heavy metal solubilization after $\mathbf{4}$ growing seasons may limit this high application rate to these soils. Based on the maximum allowable levels of $\mathrm{Cu}, \mathrm{Mn}$, and $\mathrm{Cd}$ that can be added to soils, the total possible amount of sludge than can be safely applied to the soils in this study and similar environments is $60 \mathrm{Mg} \mathrm{ha}^{-1}$.

\section{Literature Cited}

Aldon, E.F., and G. Garcia. 1972. Vegetation changes as a result of soil ripping in the Rio Puerco in New Mexico. J. Range Manage. 25:381-383. Aldon, E.F., D.G. Scholl, P.R. Fresquez, and R.E. Francis. 1988. Natural production potential of some Rio Puerco soils in New Mexico. USDA Forest Serv. Res. Note RM-481, Rocky Mountain Forest and Range Exp. Sta., Fort Collins, Colo.

AOAC. 1984. Official methods of analysis. 14th edition, Washington, D.C. Ares, J. 1976. Dynamics of the root system of blue grama. J. Range Manage. 29:208-213.

Biondini, M.E., and E.F. Redente. 1986. Interactive effect of stimulus and stress on plant community diversity in reclaimed lands. Reclam. Reveg. Res. 4:211-222. 
Black, A.L., and J.R. Wight. 1979. Range fertilization: Nitrogen and phosphorus uptake and recovery over time. J. Range Manage. 32:348-353. Bohn, H., B. MeNeal, and G. O'Conner. 1979. Soil chemistry. Wiley Interscience, New York, N.Y.

Budd, B. 1989. Snakeweed: rangeland enemy. NM Resources 2:14.

Dennis, G.L., and P.R. Fresquez. 1989. The soil microbial community in a sewage sludge amended semiarid grassland. Bio. Fert. Soils 7:310-317.

Dortignac, E.J. 1960. The Rio Puerco-past, present, and future. NM Water Conserv. Proc. 5:45-51.

Dwyer, D.D. 1971. Nitrogen fertilization of blue grama range in the foothill of south-central New Mexico. NMSU Agr. Exp. Sta. Bull. 585.

Erickson, A.E. 1973. Physical changes to soils used for land application of municipal wastes. p. 75-135. In: Proc. Joint Conference on Recycling Municipal Sludges and Effluents on Land. Champaign, Illinois Nat. Tech. Inform. Ser. U.S. PB-227106, U.S. Dept. Commerce.

Ettershank, G., J. Ettershank, M. Bryant, and W.G. Whitford. 1978. Effects of nitrogen fertilization on primary production in a Chihuahuan Desert ecosystem. J. Arid Environ. 1:135-139.

Francis, R.E. 1986. Phyto-edaphic communities of the Upper Rio Puerco Watershed, New Mexico. USDA Forest Serv. Res. Pap. RM-272, Rocky Mountain Forest and Range Exp. Sta., Fort Collins, Colo.

Fresquez, P.R., E.F. Aldon, and G.L. Dennis. 1988a. Carbon dioxide evolution from an organically amended Rio Puerco soil. USDA Forest Serv. Res. Note RM-480, Rocky Mountain Forest and Range Exp. Sta., Fort Collins, Colo.

Fresquez, P.R., R.E. Francis, and G.L. Dennis. 1988b. Fungal communities associated with phytoedaphic communities in the semiarid Southwest. Arid Soil Res. Rehab. 2:187-202.

Fresquez, P.R., R.E. Francis, and G.L. Dennis. 1990. Influence of sewage sludge on soil and plant quality in a degraded semiarid grassland. J. Environ. Qual. 19:324-330.

Gesink, R.W., H.P. Alley, and G.A. Lee. 1973. Vegetative response to chemical control of broom snakeweed on a blue grama range. J. Range Manage. 26:139-143.

Greig-Smith, P. 1983. Quantitative plant ecology. Third ed. Univ. California Press, Berkeley.

Hayes, D.C., and T.R. Seastedt. 1987. Root dynamics of tallgrass prairie in wet and dry years. Can. J. Bot. 65:787-791.

Hickey, W.C., and E.J. Dortignac. 1964. An evaluation of soil ripping and soil pitting on runoff and erosion in the semiarid Southwest. Inter. Assoc. Sci. Hydrol. 65:22-23.

Houston, J. 1979. A general hypotheses of species diversity. Amer. Nat. 113:81-101

Jameson, D.A. 1966. Competition in a blue grama-snakeweed-actinea community and responses to selective herbicides. J. Range Manage. 19:121-124

Ludwig, J.A., W.G. Whitford, and J.M. Cornelius. 1989. Effects of water, nitrogen and sulfur amendments on cover, density and size of Chihuahuan Desert ephemerals. J. Arid Environ. 16:35-42.
McCaslin, B.D., and G.A. O'Conner. 1982. Potential fertilizer value of gamma-irradiated sewage sludge on calcareous soil. NM Agr. Exp. Sta. Bull. 692.

McDaniel, K.C., R.D. Pieper, and G.B. Donart. 1982. Grass response following thinning of broom snakeweed. J. Range Manage. 35:219-222.

McDaniel, K.C., R.D. Pieper, L.E. Loomis, and A.A. Osmun. 1984. Taxonomy and ecology of perennial snakeweeds in New Mexico. N.M. Agr. Exp. Sta. 711.

Morris, M.J. 1973. Estimating understory plant cover with rated microplots. USDA Forest Serv. Res. Pap. RM-104, Rocky Mountain Forest and Range Exp. Sta., Fort Collins, Colo.

Pase, C.P. 1981. Community structure analysis-a rapid, effective range condition estimator for semi-arid ranges. p. 425-430. In: Arid land resource inventories: Developing cost-efficient methods. (Nov, 30-Dec. 6, 1980, LaPaz, Mexico. H.G. Lund, et al. tech. coord. USDA For. Serv. Gen. Tech. Rep. WO-28, Washington, D.C.

Pleper, R.D., D.D. Dwyer, and W.W. Wile. 1973. Burning and fertilizing blue grama range in south-central New Mexico. NMSU Agr. Exp. Sta. Bull. 611 .

Schafer, W.M. 1979. Guides for estimating cover-soil quality and mine soil capability for use in coal stripmine reclamation in the western U.S. Reclam. Rev. 2:67-74.

Scholl, D.G., and E.F. Aldon. 1988. Runoff and sediment yield from two semiarid yield from two semiarid sites in New Mexico's Rio Puerco Watershed. USDA Forest Serv. Res. Note RM-488, Rocky Mountain Forest and Range Exp. Sta., Fort Collins, Colo.

Singh, J.S., and D.C. Coleman. 1977. Evaluation of functional root biomass and translocation of photoassimilated ${ }^{14} \mathrm{C}$ in a shortgrass prairie ecosystem. p. 123-132. In. J.K. Marshall (ed.), The Belowground Ecosystem: A synthesis of plant-associated processes, Range Sci. Dep. Sci. Ser. No. 26, Fort Collins, Colo.

Sommers, L.W. 1977. Chemical composition of sewage sludges and analysis of their potential use as fertilizers. J. Environ. Qual, 6:225-232.

Tiedemann, A.R., and C.F. Lopez. 1982. Soil nutrient assessments of mine spoils. p. 66-79. In. E.F. Aldon and W.R. Oaks (eds.), Reclamation of Mined lands in the Southwest (Oct. 20-22, Albuquerque, NM).

Tilman, D. 1982. Resource competition and community structure. Princeton Univ. Press, Princeton, N.J.

USDA. 1986. Preliminary soil survey of Sandoval County, New Mexico. Soil Conservation Service, Albuquerque, N.M.

Waite, D.B. 1972. Rio Puerco Spec. Pro. Rep. U.S. Dep. Interior, Bureau of Land Management, Santa Fe, N.M.

Whitford, W., E.F. Aldon, D.W. Freckman, Y. Steinberger, and L.W. Parker. 1989. The effects of organic amendments on soil biota on a degraded rangeland. J. Range Manage. 42:56-60.

Wilm, H.G., D.F. Costello, and G.E. KIpple. 1944. Estimating forage yield by the double-sampling method. J. Amer. Soc. Agron. 36:194-203. 